\title{
ЗНАЧЕННЯ ПСИХОЛОГІЧНОЇ КУЛЬТУРИ В ПРОЦЕСІ ФОРМУВАННЯ ОСОБИСТОСТІ МАЙБУТНЬОГО ПЕДАГОГА
}

\section{Пухно Світлана Валерївна}

\author{
Кандидат психологічних наук, доиент кафедри \\ психології Навчально-наукового інституту педа- \\ гогіки і психології Сумського державного педагогі- \\ чного університету імені А. С. Макаренка, м. Су- \\ ми (Украӥна)
}

ORCID ID: https://orcid.org/0000-0003-0657-442X

\begin{abstract}
Анотація. У статті викладено теоретичний аналіз поняття «психологічна культура особистості» та розвиток компонентів изього феномену під час навчання студентів - майбутніх педагогів у закладах вищої освіти. Проаналізовано компоненти психологічної культури: когнітивний, рефлексивно-перцептивний, комунікативний, регулятивний, ціннісно-смисловий. Представлено, щуо формування вказаних складових психологічної культури студентів відбувається внаслідок трансформації особистісних характеристик майбутніх педагогів в ході навчальної діяльності за умови впровадження інновачійних педагогічних технологій. У результаті проведеного експериментального дослідження визначені особливості самооиінки професійно важливих педагогічних якостей та професійної спрямованості особистості майбутніх вчителів інформатики, математики, фізики; показано, щзо проиес формування особистості майбутнього педагога безпосередньо пов 'язаний з формуванням складових психологічної культури особистості.
\end{abstract}

Ключові слова: когнітивний, комунікативний, регулятивний, рефлексивнопериептивний, ціннісно-смисловий компоненти психологічної культури, професійно важливі педагогічні якості, професійна спрямованість особистості вчителя.

Постановка проблеми. Проблеми формування компетенцій майбутнього фахівця, відповідних тій чи іншій професії, на сьогодні $\epsilon$ актуальними для сучасних досліджень у га- лузі психології. Враховуючи те, що педагогічна діяльність сьогодні є однією з складних, проблеми формування особистості майбутнього вчителя і значення психологічної культури 
в цьому процесі вимагають значної уваги. До завдань вищих закладів освіти відноситься формування компетентної у професійній діяльності особистості зі сформованою комунікативною культурою та вміннями побудови ефективних моделей взаємодії, і тому проблеми формування психологічної культури майбутнього педагога $\epsilon$ актуальними для сучасних досліджень [1-7]. Крім цього, саме в процесі навчання дисциплін курсів, виконання завдань самостійної навчально-дослідницької та науково-дослідної роботи, проходження всіх видів практики, формуються професійні якості майбутніх педагогів, їх оцінка власних професійних педагогічних якостей та особливості професійної спрямованості.

За В. В. Семакіним, розвиток психологічної культури особистості має певну динаміку: по-перше - набуття людиною психологічної грамотності (оволодіння психологічними знаннями, вміннями, навичками), необхідними для соціалізації на різних етапах іiї професійного життя; надалі - формування психологічної компетентності - можливості практичної реалізації психологічного знання та навичок, формування вмінь. Психологічна культура як розвинений механізм особистісної саморегуляції - це третій рівень представленої генези, який постає головним чинником формування особистості майбутнього педагога [7, с. 33]. Відповідно, проблеми організації навчально-виховного процесу закладів вищої освіти 3 метою формування компонентів психологіч- ної культури майбутнього педагога є актуальними для сучасних дослідницьких пошуків.

\section{Аналіз останніх досліджень і публіка-}

цій. Проблемам формування психологічної культури майбутнього педагога присвячені дослідження Г. С. Батищєва, Т. В. Іванової, М. С. Каган, В. Б. Лагутіна, Н. І. Мачинської, Л. О. Нестеренко, А. А. Осипової, О. М. Попенко, С. В. Пухно, А. І. Салтикової, В. В. Семікина, Т. Б. Тарасової, Г. С. Улунової та багатьох інших. Вказаним проблемам присвячена серія авторських праць [3-5]. Дослідження значення психологічної культури в процесі формування особистості майбутнього педагога, зокрема, - самооцінки професійно важливих якостей майбутнього фахівця та професійна спрямованість вчителя, на сьогодні вимагає більшої дослідницької уваги. Актуальною проблемою є розробка ефективних механізмів формування складових психологічної культури майбутніх педагогів шляхом впровадження в навчальний процес закладів освіти інноваційних методів навчання.

Мета статті полягає у дослідженні значення психологічної культури в процесі формування таких складових особистості майбутнього педагога як самооцінки професійно важливих педагогічних якостей та професійної спрямованості особистості вчителя.

Методи дослідження. Для досягнення мети дослідження використані методи комплексного аналізу; в емпіричній частині дослідження використовувались психологічні мето- 
дики «Карта самооцінки професійно важливих якостей майбутнього вчителя» та «Професійна спрямованість особистості вчителя» (Є. І. Рогов).

Виклад основного матеріалу i peзультатів дослідження. Згідно теоретичного доробку Г. С. Улунової, психологічна культуpa $є$ особистісним динамічним утворенням i складовою професійної культури, що забезпечує самореалізацію особистості як суб'єкта професійної діяльності [7]. Психологічна культура педагога містить когнітивний, рефлексивно-перцептивний, комунікативний, регулятивний та ціннісно-смисловий компоненти [1, c. 234-235]. Перший полягає у наявності психологічних знань, що, зокрема, дозволяє оцінювати людині власні особистісні характеристики. Майбутні педагоги - студенти Сумського державного педагогічного університету імені А. С. Макаренка набувають психологічні знання з загальної, соціальної та вікової психології в ході вивчення дисципліни «Психологія». Ця дисципліна надає можливість не просто опановувати систему психологічного знання, як складову педагогічної діяльності, але і на цій основі формується наступна складова психологічної культури - рефлексивно-перцептивна, що допомагає формуванню педагогічної «проникливості» - прогностичних педагогічних здібностей. Усвідомлення як власних психологічних змін, так і змін, що відбуваються в психічному світі інших людей в процесі взаємодії, свідчить про роз- виток педагогічної емпатії і рефлексії і є вищім рівнем трансформації теоретичного знання. Це - афективний компонент психологічної культури. Комунікативний та регулятивний компонент полягає в наявності сформованих комунікативних навичок, умінні керувати емоційними станами, оцінювати та коректувати індивідуально-психологічну особистісну сферу. Сформовані структури визначених компонентів психологічної культури - це ціннісно-смислова складова, - система соціальних норм і цінностей педагога як члена суспільства, громадянина, який виконує виховні функції.

3 метою формування складових психологічної культури майбутніх педагогів, під час вивчення дисципліни «Психологія» впроваджено дискусійні форми роботи на практичних заняттях, участь студентів у роботі наукового гуртка «Актуальні проблеми психології особистості» та наукових конференціях (Міжнародна науково-практична конференція студентів, аспірантів та фахівців у галузі психології «Молодь в сучасній психології. Етнічна самосвідомість та міжетнічна взаємодія»; Міжнародна науково-практична конференція «Особистість у кризових умовах та критичних ситуаціях життя»; Студентська звітна конференція за матеріалами результатів наукових досліджень молодих науковців фізикоматематичного факультету Сумського державного педагогічного університету імені А. С. Макаренка), що сприяє оволодінню ними на- 
вичок науково-дослідної роботи, формування компетенцій майбутньої педагогічної діяльності. Інноваційні педагогічні технології у процесі вивчення дисципліни «Психологія», зокрема, - така форми роботи як тренінг, є необхідними складовими формування психологічної культури студентів, оскільки орієнтовані на вироблення ефективних моделей поведінки та обмін соціальним досвідом. В ході вивчення дисципліни «Психологія», студенти фізик математичного факультету приймають участь у роботі тренінгів ефективної комунікації. Включення в тренінгову роботу сприяють формуванню у майбутніх педагогів комунікативно-організаційних вмінь, навичок самопрезентації, взаємодії, доланню бар'єрів спілкування [3].

3 метою визначення значення психологічної культури в процесі формування таких складових особистості майбутнього педагога як самооцінки професійно важливих якостей та професійної спрямованості особистості вчителя, протягом 2018-2019 навчального року на базі фізико-математичного факультету Сумського державного педагогічного університету імені А. С. Макаренка було проведено дослідження, в якому приймали участь 30 магістрантів - майбутніх вчителів інформатики, математики фізики. Всі учасники мають педагогічний досвід - проходження тривалої педагогічної практики, робота в дитячих центрах, загальноосвітніх школах, коледжах. Протягом навчання на I-II курсі ці студенти вивчали ди- сципліни «Психологія», «Педагогіка», виконували індивідуальні навчально-дослідні завдання за тематикою загальної, соціальної, вікової та педагогічної психології, приймали участь у комунікативних тренінгах, були членами студентських наукових гуртків, приймали участь з результатами авторських досліджень 3 актуальних проблем психології у наукових конференціях.

В ході першого етапу дослідження визначалась самооцінка професійно важливих якостей майбутнього педагога за методикою «Карта самооцінки професійно важливих якостей майбутнього вчителя». Другий етап був присвячений вивченню оцінки професійної спрямованості особистості вчителя на основі психологічної методики «Професійна спрямованість особистості вчителя» (С. І. Рогов).

Самооцінка професійно важливих якостей майбутнього педагога - динамічне утворення, що формується внаслідок розвитку необхідних особистісних і професійних оцінок людиною своїх потенційних якостей як майбутнього фахівця у педагогічній галузі. Формування складових психологічної культури $є$ чинником об'єктивної самооцінки професійно важливих якостей майбутнього вчителя: студенти, що володіють як системою необхідного психологічного знання, так і рефлексивним мисленням, в процесі педагогічної діяльності, об'єктивно оцінюють свої професійні характеристики і усвідомлюють потребу розвитку певних якостей [4]. 
Згідно аналізу результатів проведеного дослідження самооцінки професійно важливих якостей майбутніх вчителів інформатики, математики фізики за методикою «Карта самооцінки професійно важливих якостей майбутнього вчителя», отримані наступні дані. Методика містить 14 професійно важливих якостей вчителя і учасникам дослідження пропонувалось оцінити власні характеристики відповідно до визначених якостей за п'ятибаловою шкалою. Найвищий показник (5 балів) надається за умови, що представлена якість $€$ типовою для педагога, систематично проявляється в діяльності і поведінці; 4 бали - якість виявляється достатньою мірою, проте, - непостійна; 3 бали - якість $€$ недостатньо розвиненою і потребує формування; 2 бали - якість сформована на недостатньому рівні, частіше проявляється в діяльності їй протилежна. Результати діагностики надають можливість визначити рівень оцінки майбутніми педагогами власних професійних особливостей.

До професійно важливих якостей майбутнього педагога, які містить методика, відносяться: політичні переконання; загальна культура, ерудиція; професійно-педагогічна спрямованість; моральні якості; вольові якості; дидактичні здібності; експресивно-мовні здібності; академічні здібності; організаційні здібності; комунікативні здібності; перцептивні здібності; авторитарні здібності; педагогічна уява; здібності розподіляти увагу на уроці. Оцінка цих якостей може бути надана лише за умови усвідомлення студентом рівня їх сформованості у власній структурі професійних здібностей.

Згідно результатам дослідження встановлено, що такі професійно-важливі якості, як політичні переконання, 80\% опитаних оцінюють як типовими для педагогічної діяльності, а 20\% - вираженою достатньою мірою, що свідчить про патріотизм, сформовану громадянську позицію молодих людей, здатності до об'єктивного аналізу сучасної політичної і соціально-економічної ситуації. 43,3\% опитаних оцінили на високому рівні власну загальну культуру та ерудицію, 50\% відмітили цю якість вираженою достатньою мірою, що свідчить про сприймання магістрантами себе як людьми високого рівня культури, що володіють науково-гуманістичним світоглядом, грунтовною системою знань. 26,7\% опитаних як типову, а $60 \%$ - як сформовану на достатньому рівні, оцінили професійно-педагогічну спрямованість, що виявляється в інтересі і повазі до особистості іншої людини,зокрема, дитини; уміння зацікавити власним задумом; прагненні до поширення наукового знання, високої ступені особистої відповідальності за навчально-виховний процес i його наслідки для кожного учасника; високого рівня вимогливості до власних особистісних і професійних характеристик; прагненні до особистісного і професійного розвитку і самовдосконалення.

Розвинуті моральні якості як типові 
професійні якості для себе визначили 33,3\%, а $60 \%$ - сформовані на достатньому рівні, що свідчить про гуманістичну професійну спрямованість майбутніх педагогів: усвідомлення цінності особистості вихованця, їі індивідуальності і неповторності. Отримані результати свідчать про усвідомлення магістрантами соціальної значущості педагогічної професії.

В оцінці таких професійних якостей, як вольові, типовими визначили ці власні якості $26,7 \%$ опитаних, а 63,3\% зазначили про достатній рівень, що свідчить про емоційну стабільність майбутніх вчителів, самоконтроль і саморегуляцію, здатність швидко приймати прогнозовані рішення.

Дидактичні здібності як типові визначили $16,7 \%$ опитаних магістрантів, про достатній рівень вказали 60\%. Ці здібності полягають у доступності передавати учням навчальний матеріал, формулювати проблему, підтримувати інтерес до матеріалу вивчення, спонукати учнів до самостійності та критичності мислення, організовувати їх самостійну роботу.

Як типовими експресивно-мовні здібності оцінили 16,7\% учасників дослідження, $46,7 \%$ вказали на достатній рівень. Сучасному педагогу необхідні вміння чіткого висловлювання своїх думок, почуттів, використання всіх можливостей невербальних засобів спілкування, високий рівень вербального інтелекту.

Відповідно до оцінки академічних здіб- ностей, майбутні педагоги визначились наступним чином: типовими визначили ці здібності $13,3 \%$ опитаних, сформованими на достатньому рівні - 60\%. Академічні здібності, як здібності до певної галузі знань, що вимагають від вчителя широкого спектру не лише спеціального знання, - сучасність вимагає постійного розширення діапазону професійних знань вчителя, обізнаності щодо останніх наукових досягнень, прагнення до дослідницької діяльносTi.

Самооцінка організаторських здібностей майбутніх педагогів, що полягають у здібностях організації учнівського колективу та власної професійної діяльності, представлена наступним чином - типовою професійною якістю визнали для себе 36,7\% магістрантів, про достатній рівень сформованості заявили 50\% опитаних. Організація власної діяльності передбачає вміння планування і самоконтролю, самоорганізації.

$36,7 \%$ опитаних оцінили власні комунікативні здібності типовими для професійної діяльності. Це проявляється у здібностях до спілкування з учнями різних вікових періодів, організації ефективної взаємодії, встановлення доцільних, з педагогічної точки зору, відносин 3 усіма учасниками навчально-виховного процесу, наявність педагогічного такту. 53,3\% визнали ці якості на достатньому рівні.

В оцінці перцептивних здібностей, $16,7 \%$ зазначили про сформованість цих якостей на найвищому рівні, достатній рівень ви- 
знали у себе $30 \% .53,3 \%$ зазначили, що ці якості проявляються не завжди. Вказані здібності полягають у вмінні «проникати» у внутрішній світ учнів (психічних станів, проявів індивідуально-психологічної сфери), наявність психологічної спостережливості, розвиненої емптії і рефлексії. Перцептивні здібності забезпечують розвиток педагогічного прогнозування наслідків навчально-виховного процесу.

Авторитарні здібності як типові для себе визначили 6,7\% опитаних, здібності, як сформовані на достатньому рівні, оцінили $40 \%$ і як про якості, що проявляються не завжди, вказали 50\%. Авторитарні здібності полягають у безпосередньому емоційному впливі на учнів і вміння завойовувати авторитет, що вимагає сформованих вольових якостей, почуття відповідальності за навчальновиховний процес в цілому, високого рівня професійних знань.

Такі професійні якості, як здібності педагогічної уяви, як типові визначили 6,7\% учасників дослідження, у 70\% - сформовані на достатньому рівні, а 20\% вказали, що якості проявляються не завжди. Професійна діяльність педагога вимагає високого рівня розвитку всіх видів пам'яті, теоретичного мислення, творчої уяви, що проявляється у можливості передбачення наслідків організації і здійснення навчально-виховного процесу, в умінні прогнозувати розвиток особистісних якостей учнів, оволодіння ними навчальним матеріалом.
Як типові оцінили здібності розподіляти увагу на уроці 20\% магістрантів, у 56,7\% самооцінка цих здібностей на достатньому рівні і у 23,3\% ці якості проявляються не завжди. Ці здібності полягають у наявності високого рівня концентрації, обсягу, переключення, стійкості і розподілу уваги, координації рухів, високому рівні самоконтролю, швидкості реакцій. Необхідність цих здібностей полягає у потребі вчителя організовувати і координувати навчальний процес та діяльність учнів, реагувати на ознаки втоми, втрати інтересу, нерозуміння, неуважність і, відповідно до цього, організовувати і контролювати свою професійну діяльність.

Можна зазначити, що магістранти на достатньо високому рівні оцінюють власні професійні педагогічні здібності. Результати першого етапу дослідження представлені в наступній таблиці 1.

Згідно проведення другого етапу дослідження - вивчення оцінки професійної спрямованості особистості вчителя, було визначено наступне. Відповідно до результатів опитування магістрантів - майбутніх вчителів інформатики, математики, фізики, що приймали участь у першому етапі, за питаннями методики «Оцінка професійної спрямованості особистості вчителя» (С. І. Рогов), яка містить 50 питань-тверджень, які оцінюються з точки зору відповідності щодо власної поведінки, визначені такі дані. В опитуванні приймали участь 30 магістрантів. В результаті даних за ме- 
Табличя 1.

\section{Оцінка професійно важливих професійних педагогічних якостей магістрантами - майбутніми вчителями інформатики, математики, фізики}

\begin{tabular}{|c|c|c|c|}
\hline $\begin{array}{c}\text { Оцінка професійно } \\
\text { важливої якості як } \\
\text { типової }\end{array}$ & $\begin{array}{c}\text { Оцінка професійно } \\
\text { важливої якості, що } \\
\text { виявляється на до- } \\
\text { статньому рівні, } \\
\text { проте, - непостійно }\end{array}$ & $\begin{array}{c}\text { Оцінка професійно } \\
\text { важливої якості, що } \\
\text { виявляється недостат- } \\
\text { ньо і потребує форму- } \\
\text { вання }\end{array}$ & $\begin{array}{c}\text { Оцінка професійно ва- } \\
\text { жливої якості на недо- } \\
\text { статньому рівні, прояв } \\
\text { в діяльності їй протиле- } \\
\text { жної }\end{array}$ \\
\hline \multicolumn{4}{|c|}{ політичні переконання } \\
\hline $80 \%$ & $20 \%$ & & \\
\hline \multicolumn{4}{|c|}{ загальна культура, ерудиція } \\
\hline $43,3 \%$ & $50 \%$ & $3,3 \%$ & \\
\hline \multicolumn{4}{|c|}{ професійно-педагогічна спрямованість } \\
\hline $26,7 \%$ & $60 \%$ & $13,3 \%$ & \\
\hline \multicolumn{4}{|c|}{ моральні якості } \\
\hline $33,3 \%$ & $60 \%$ & $6,7 \%$ & \\
\hline \multicolumn{4}{|c|}{ вольові якості } \\
\hline $26,7 \%$ & $63,3 \%$ & $10 \%$ & \\
\hline \multicolumn{4}{|c|}{ дидактичні здібності } \\
\hline $16,7 \%$ & $60 \%$ & $3,3 \%$ & \\
\hline \multicolumn{4}{|c|}{ експресивно-мовні здібності } \\
\hline $16,7 \%$ & $46,7 \%$ & $36,7 \%$. & \\
\hline \multicolumn{4}{|c|}{ академічні здібності } \\
\hline $13,3 \%$ & $60 \%$ & $23,3 \%$ & $3,3 \%$ \\
\hline \multicolumn{4}{|c|}{ організаторські здібності } \\
\hline $36,7 \%$ & $50 \%$ & $13,3 \%$ & \\
\hline \multicolumn{4}{|c|}{ комунікативні здібності } \\
\hline $36,7 \%$ & $53,3 \%$ & $10 \%$ & \\
\hline \multicolumn{4}{|c|}{ перцептивні здібності } \\
\hline $16,7 \%$ & $30 \%$ & $53,3 \%$ & \\
\hline \multicolumn{4}{|c|}{ авторитарні здібності } \\
\hline & $6,7 \%$ & $50 \%$ & $3,3 \%$ \\
\hline \multicolumn{4}{|c|}{ здібності педагогічної уяви } \\
\hline $6,7 \%$ & $70 \%$ & $20 \%$ & $3,3 \%$ \\
\hline \multicolumn{4}{|c|}{ здібності розподіляти увагу на уроці } \\
\hline $20 \%$ & $56,7 \%$ & $23,3 \%$ & \\
\hline
\end{tabular}

тодикою виділені наступні напрямки професійної спрямованості педагога:

тип «Предметник», «Організатор», «Комунікатор»; «Інтелігент».
Методика містить питання-твердження i кожен особистісний параметр оцінюється сумуванням оцінок за групою питань. Професійна спрямованість особистості вчителя ви- 
Значається шляхом сумарної оцінки за всіма питаннями. В результаті дослідження визначено, що 20\% опитаних відносяться до професійної спрямованості особистості вчителя за типом «Організатор»; 46,7\% - до професійної спрямованості за типом «Предметник», 20\% визначили особистісні характеристики професійної спрямованості за типом «Комунікатор» і 13,3\% - «Інтелігент». Результати другого етапу дослідження представлені в наступній таблиці 2. ритаризму, прагнути організовувати діяльність інших. До якостей наступного типу професійної спрямованості - «Комунікатор», відносяться комунікабельність, зовнішня привабливість, моральність, емоційність, пластичність, прагнення зменшення дистанції з партнерами, екстравертованість, низька конфліктність, високий рівень емпатії. Для «Предметника» характерні спостережливість, професійна компетентність, прагнення до творчості. Згідно дослідницьким даним, іноді від-

Таблиия 2.

\section{Оцінка професійної спрямованості особистості вчителя магістрантами - майбутніми вчи- телями інформатики, математики, фізики}

\begin{tabular}{|c|c|c|c|}
\hline $\begin{array}{c}\text { Тип } \\
\text { «Вчитель- } \\
\text { організатор» }\end{array}$ & $\begin{array}{c}\text { Тип } \\
\text { «Вчитель- } \\
\text { предметник» }\end{array}$ & $\begin{array}{c}\text { Тип } \\
\text { «Вчитель- } \\
\text { комунікатор» }\end{array}$ & $\begin{array}{c}\text { Тип } \\
\text { «Вчитель-інтелігент». }\end{array}$ \\
\hline $20 \%$ & $46,7 \%$ & $20 \%$ & $13,3 \%$ \\
\hline
\end{tabular}

Тип «Організатор» характеризується вимогливістю, організованістю, розвиненими вольовими якостями, енергійністю. Вчительорганізатор, як правило, є лідером як у учнів, так і в педагогічному колективі; особистісні якості педагога цього типу, як правило, реалізуються в процесі позакласних заходів. Вчитель-організатор характеризується спрямованістю на співробітництво, прагненням підтримки дисципліни та активізації групової діяльності. 3 часом педагог, якому притаманні ці особливості, може ставати занадто активним, втручатися в особистісне життя інших, прагнучи «вчити життю», бути схильним до авто- бувається

поєднання

спрямованості

«Предметник-Комунікатор», що характеризується прагненням педагога більш чіткої організації навчального процесу. Тип «Інтелігент» характеризується принциповістю, «високим» інтелектом та рівнем загальної культури, дотриманням моральних норм, потребою у просвітницькій діяльності.

Вказані особливості типів педагогів можуть 3 часом проявлятися в структурі особистості, тому, визначення професійної спрямованості, згідно даним досліджень, надають змогу попередження професійної деформації особистості. 
Відповідно до особливостей, що входять до кола професійної особистісної спрямованості, кожним вчителем краще реалізовуються певні функції професійної діяльності. Так, «Організатор» більш ефективно виконує виконавчу, мобілізаційну і організаторську функції. Відповідно, це забезпечується розвитком комунікативних, перцептивних, вольових, авторитарних, організаторських і експресивно-мовних здібностей. «Предметник» ефективно реалізує конструктивну, методичну, навчальну і орієнтувальну функції. Вказане потребує розвитку академічних, дидактичних і комунікативних здібностей, педагогічної уяви, здібностей розподіляти увагу на уроці. «Інтелігент» якісно виконує гностичну, виховну, інформаційну, пропагандистську, розвиваючу і дослідницьку функцію, а також функції самовдосконалення. Це неможливо без розвитку загальної культури, ерудиції, системи стійких політичних переконань, моральних якостей, професійно-педагогічної спрямованості. В результаті проведення бесіди на завершальному етапі дослідження визначено усвідомлення учасниками необхідності участі у програмах семінарів-тренінгів 3 метою розвитку визначених педагогічних здібностей.

Висновки та перспективи подальших досліджень. Психологічна культура особистості постає умовою саморозвитку особистості майбутнього педагога. Розвиток компонентів психологічної культури відбувається внаслідок трансформації особистісних власти- востей і якостей майбутніх фахівців за умови впровадження інноваційних педагогічних технологій у навчальний процес закладів вищої освіти. В результаті проведення дослідження щодо самооцінки професійно важливих якостей та професійної спрямованості особистості майбутніх вчителів інформатики, математики, фізики, можна зазначити, що для майбутніх педагогів велике значення має володіння професійними знаннями, дидактикою та методикою викладання предметів, організації навчального процесу загалом.

Відповідно до результатів дослідження самооцінки професійно важливих якостей майбутнього педагога, можна виділити, що магістранти Сумського державного педагогічного університету імені А. С. Макаренка мають сформовані політичні переконання, що свідчить про патріотизм молодих людей, сформовану громадянську позицію, здатність до об'єктивного аналізу сучасної політичної i соціально-економічної ситуації; володіють науково-гуманістичним світоглядом, грунтовною системою знань. Більшість учасників опитування $(86,7 \%)$ мають визначену професійно-педагогічну спрямованість, що виражається в прагненні до поширення наукового знання, високої ступені особистої відповідальності за навчально-виховний процес; вимогливості в оцінці власних професійних характеристик, прагненні до особистісного і професійного самовдосконалення. Результати дослідження свідчать про те, що авторитарні здіб- 
ності 50\% опитаних оцінюють як якості, що проявляються не завжди. Авторитарні здібності полягають у безпосередньому емоційному впливі на учнів, педагогічному такті і вимагають високого рівня професійних знань, які, як правило, набуваються з досвідом в ході безпосередньої педагогічної діяльності. В результаті дослідження визначено, що майбутні педагоги переживають складність розвитку перцептивних педагогічних професійних здібностей, які надають можливість ефективної організації взаємодії з усіма учасниками навчально-виховного процесу, i розвиток яких, в свою чергу, пов'язаний з прогностичною функцією (педагогічною уявою). Остання надає можливість педагогу об'єктивно оцінювати організацію навчально-виховного процесу i передбачати результати педагогічних впливів.

Згідно проведення другого етапу дослідження - вивчення оцінки професійної спрямованості особистості вчителя, було визначено, що для більшості опитаних молодих людей $(46,7 \%)$ характерною є професійна спрямованість за типом «Вчитель - предметник», що свідчить про сформованість професійної компетентності майбутніх педагогів, прагнення до педагогічної творчості та новаторства. Майбутні вчителі розуміють завдання професійної діяльності, що полягають у ефективній реалізації конструктивної, методичної, навчальної функції педагогічного процесу. Вказане потребує розвитку академічних, дидактичних, комунікативних і прогностичних здібнос- тей, педагогічної уяви, здібностей розподіляти увагу на уроці, і стає можливим внаслідок впровадження в навчальний процес закладів вищої освіти інтерактивних інноваційних методів навчання. Виділені проблеми вимагають активізації уваги сучасних дослідників з галузі психології і педагогіки вищої школи з метою розробки ефективних технологій навчання.

\section{Перелік використаних джерел:}

1.Мачинська Н. I. Психологічна культура як складник професіоналізму викладача / Н. І. Мачинська, В. Б. Лагутін // Психологічна культура як складник професіоналізму викладача - Науковий вісник Львівського державного університету внутрішніх справ - 2011 - №2 C. 229-241.

2.Попенко О. М. Професійна культура вчителя як інтеграційна якість особистості педагога-професіонала / О. М. Попенко // Наукові записки НДУ ім. М. Гоголя. Психолого-педагогічні науки. - 2012 - № 1 - С.44-49.

3.Пухно С. В. Значення тренінгової роботи в процесі формування психологічної культури майбутніх вчителів фізико-математичних дисциплін / С. В. Пухно // Гуманітарний вісник ДВНЗ «Переяслав-Хмельницький державний педагогічний університет імені Григорія Сковороди». - Додаток 2 до Вип. 37: Тематичний випуск «Проблеми емпіричних досліджень у психології». - Випуск 14. - К. : Гнозис, 2017. - С. 103-111.

4.Пухно С. В. Значення психологічної культури в процесі формування самооцінки професійно важливих якостей майбутнього педагога / С. В. Пухно // Теоретичні і прикладні проблеми психології : зб. наук. праць Східноукраїнського національного університету ім. В. Даля. - Сєвєродонецьк : Вид-во СНУ ім. В. Даля, 2018. - № 2 (46). - C. 240-250.

5.Пухно С. В. Психолого-педагогічні складові форму- 
вання професійної культури майбутніх вчителів фізикоматематичних дисциплін / С. В. Пухно, А. І. Салтикова // «Професійна культура: сутність, фахові особливості, розвиток : колективна монографія / кол. авт., відп. ред. Г.Є. Улунова. - Суми : СумДПУ ім. А.С. Макарена, 2016. - С. 240-255.

6.Тарасова Т. Б. Психологічна просвіта - шлях до психологічної культури особистості / Т. Б. Тарасова // Психологічна культура: види, інваріанти, розвиток : монографія / кол. авт.. ; відп. ред. Г. С. Улунова. - Суми : ВВП «Мрія», 2014. - С. 155-175.

7.Улунова Г. Є. Психологічна культура як інваріант загальної та професійної культури / Г. Є. Улунова // Психологічна культура: види, інваріанти, розвиток : монографія / кол. авт.. ; відп. ред. Г. С. Улунова. - Суми : ВВП «Мрія», 2014. - С. 8-36.

\section{References (Transliteration):}

1.Machynska N. I. (2011). Psykholohichna kultura yak skladnyk profesionalizmu vykladacha. Naukovyi visnyk Lvivskoho derzhavnoho universytetu vnutrishnikh sprav, 2, 229-241.

2.Popenko O. M. (2012). Profesiina kultura vchytelia yak intehratsiina yakist osobystosti pedahoha-profesionala. Naukovi zapysky NDU im. M. Hoholia. Psykholohopedahohichni nauky, № 1, 44-49

3.Pukhno S. V. (2017). Znachennia treninhovoi roboty v protsesi formuvannia psykholohichnoi kultury maibutnikh vchyteliv fizyko-matematychnykh dystsyplin. Humanitarnyi visnyk DVNZ «Pereiaslav-Khmelnytskyi derzhavnyi pedahohichnyi universytet imeni Hryhoriia Skovorody». Dodatok 2 do Vyp. 37: Tematychnyi vypusk «Problemy empirychnykh doslidzhen u psykholohii», 14. K. : Hnozys, 103-111.

4.Pukhno S. V. (2018). Znachennia psykholohichnoi kultury $\mathrm{v}$ protsesi formuvannia samootsinky profesiino vazhlyvykh yakostei maibutnoho pedahoha. Teoretychni i prykladni problemy psykholohii : zb. nauk. prats
Skhidnoukrainskoho natsionalnoho universytetu im. V. Dalia. - Sievierodonetsk : Vyd-vo SNU im. V. Dalia. № 2 (46). 240-250.

5.Pukhno S. V., Saltykova A. I. (2016). Psykholohopedahohichni skladovi formuvannia profesiinoi kultury maibutnikh vchyteliv fizyko-matematychnykh dystsyplin. Profesiina kultura: sutnist, fakhovi osoblyvosti, rozvytok : kolektyvna monohrafiia / kol. avt., vidp. red. H. Ye. Ulunova. Sumy : SumDPU im. A.S. Makarena, 240-255.

6.Tarasova T. B. (2014). Psykholohichna prosvita - shliakh do psykholohichnoi kultury osobystosti. Psykholohichna kultura: vydy, invarianty, rozvytok : monohrafiia / kol. avt.. ; vidp. red.. H. Ye. Ulunova. Sumy : VVP «Mriia», 155175.

7.Ulunova H. Ye. (2014). Psykholohichna kultura yak invariant zahalnoi ta profesiinoi kultury. Psykholohichna kultura: vydy, invarianty, rozvytok : monohrafiia / kol. avt.. ; vidp. red.. H. Ye. Ulunova. Sumy : VVP «Mriia», 8-36.

\section{Pukhno Svetlana}

PhD (Psychological Sciences), Associate Professor of the Department of Psychology Educational-Scientific Institute of Pedagogy and Psychology of A.S. Makarenko Sumy State Pedagogical University, Sumy (Ukraine)

\section{VALUE OF PSYCHOLOGICAL CULTURE IN THE FORMATION PROCESS OF THE FUTURE TEACHER'S PERSONALITY}

\section{ABSTRACT}

The theoretical concept analysis of "personality psychological culture" and the components meaning of this phenomenon in the students- future teachers teaching process at the higher educational establishments are presented in the article. Psychological culture is a personal dynamic formation and a professional culture component, which ensures individual self- 
realization as the professional activity subject is determined in the study. The psychological culture components are analyzed: cognitive, reflective-perceptual, communicative, regulatory, value -semantic. It is presented that these components formation of the students' psychological culture occurs as a result of the future teachers' personal characteristics transformation in the course of educational activities subject to the innovative educational technologies introduction.

In order to determine the psychological culture value in the formational process of the future teacher's personality, during the 20182019 school year, an experimental study was conducted on the Physics and Mathematics Faculty basis of Makarenko Sumy State Pedagogical University, in which undergraduates - future teachers of computer studies, mathematics, physics have participated. All participants have got pedagogical experience: passing a long pedagogical practice, working at children health centers, secondary schools, colleges. These students have studied the disciplines "Psychology", "Pedagogy" during the I-II courses, performed individual educational research tasks and research on topical issues of general, social, age and pedagogical psychology, pedagogy, participated in social trainings, were members of student scientific circles, participated with author's research results at scientific conferences.

As a result of the first study stage, the self-esteem features of the professionally important pedagogical qualities of future teachers' of computer studies, mathematics, and physics were identified. This is a dynamic formation, which is provided due to the person's assessments of his potential qualities as a future specialist. The formation of psychological culture components is a factor in objective self-esteem of the future teacher's professionally important qualities: students, who have got psychological knowledge and reflexive thinking system, objectively assess their professional characteristics and realize the need for their development. The study results indicate that undergraduates of Makarenko Sumy State Pedagogical University evaluate their own professionally important qualities as future teachers at a high level, as political convictions, general culture, erudition, professional pedagogical orientation, moral and volitional qualities, didactic and expressive speech abilities, academic and organizational communication skills. Such professionally important pedagogical qualities as perceptual abilities, pedagogical imagination, abilities to distribute attention at the lesson and authoritarian abilities are assessed by undergraduates at an insufficient level, which requires extrawork on their development.

As a result of the second study part, the professional orientation features of future teachers of computer studies, mathematics, and physics were determined. It is presented that for the majority of studied young people, a professional type orientation "Teacher-Subject" is characteristic, which indicates the future teachers' professional competence acceleration, the desire for 
pedagogical creativity and innovation. This requires the academic, didactic, communicative and prognostic abilities development, which is possible providing innovative educational methods into the educational process of the higher educational establishments. These problems require the modern researchers' attention in the psychology and pedagogy field of higher education in order to develop effective teaching technologies.

Key words: cognitive, communicative, regulatory, reflective-perceptual, value-semantic component of psychological culture, professionally important pedagogical qualities, teacher's professional orientation.

\section{Пухно Светлана Валериевна}

Кандидат психологических наук, дочент кафедры психологии Учебно-научного института педагогики и психологии Сумского государственного педагогического университета имени А. С. Макаренко, г. Суммы (Украина)

\section{ЗНАЧЕНИЕ ПСИХОЛОГИЧЕСКОЙ КУЛЬТУРЫ В ПРОЦЕССЕ ФОРМИРОВАНИЯ ЛИЧНОСТИ БУДУЩЕГО ПЕДАГОГА}

Аннотация. В статье представлен теоретический анализ понятия «психологическая культура личности» и значение компонентов этого феномена в процессе обучения студентов - будущих педагогов в высших учебных заведениях. В ходе исследования определено, что психологическая культура является личностным динамическим образованием и со- ставляющей профессиональной культуры, что обеспечивает самореализацию личности как субъекта профессиональной деятельности. Проанализированы компоненты психологической культуры: когнитивный, рефлексивноперцептивный, коммуникативный, регулятивный, ценностно-смысловой. Представлено, что формирование указанных составляющих психологической культуры студентов происходит вследствие трансформации личностных характеристик будущих педагогов в ходе учебной деятельности при условии введения инновационных педагогических технологий.

С целью определения значения психологической культуры в процессе формирования личности будущего педагога, на протяжении 2018-2019 учебного года на базе физикоматематического факультета Сумского государственного педагогического университета имени А. С. Макаренко было проведено экспериментальное исследование, в котором принимали участие магистранты - будущие учителя информатики, математики, физики. Все участники имеют педагогический опыт: прохождение длительной педагогической практики, работа в детских оздоровительных центрах, общеобразовательных школах, колледжах. На протяжении обучения на I-II курсах эти студенты изучали дисциплины «Психология», «Педагогика», выполняли индивидуальные учебно-исследовательские задания и научные исследования по актуальным проблемам общей, социальной, возрастной и 
педагогической психологии, педагогики, принимали участие в коммуникативных тренингах, были членами студенческих научных кружков, принимали участие с результатами авторских исследований в научных конференциях. В результате первого этапа исследования были определены особенности самооценки профессионально важных педагогических качеств будущих учителей информатики, математики, физики. Это - динамическое образование, которое формируется вследствие развития необходимых личностных и профессиональных оценок человеком своих потенциальных качеств как будущего специалиста. Формирование составляющих психологической культуры является фактором объективной самооценки профессионально важных качеств будущего учителя: студенты, которые владеют системой психологического знания и рефлексивным мышлением, объективно оценивают свои профессиональные характеристики и осознают необходимость их развития. Полученные результаты исследования свидетельствуют о том, что магистранты Сумского государственного педагогического университета имени А. С. Макаренко оценивают на высоком уровне собственные профессионально важные качества будущего учителя, как политические убеждения, общую культуру, эрудицию, профессионально-педагогическую направленность, моральные и волевые качества, дидактические и экспрессивно-речевые способности, академические и организационно- коммуникативные способности. Такие профессионально важные педагогические качества, как перцептивные способности, педагогическое воображение, способности распределять внимание на уроке и авторитарные способности оцениваются магистрантами сформированными на недостаточном уровне, что требует работы над их развитием.

В результате проведения второй части исследования определены особенности профессиональной направленности будущих учителей информатики, математики, физики. Представлено, что для большинства опрошенных молодых людей характерной является профессиональная направленность по типу «Учитель-предметник», что свидетельствует о формировании профессиональной компетентности будущих педагогов, стремления к педагогическому творчеству и новаторству. Это требует развития академических, дидактических, коммуникативных и прогностических способностей, что возможно при условии внедрения в учебный процесс высших учебных заведений интерактивных инновационных методов обучения. Эти проблемы требуют внимания современных исследователей в области психологии и педагогики высшей школы с целью разработки эффективных технологий обучения.

Ключевые слова: когнитивный, коммуникативный, регулятивный, рефлексивноперцептивный, ценностно-смысловой компоненты психологической культуры, профессио- 
нально важные педагогические качества, профессиональная направленность личности учителя. 